\title{
ANALYSIS OF KARAWANG ONLINE SALES CUSTOMER SATISFACTION USING CUSTOMER SATISFACTION INDEX (CSI) METHOD
}

\author{
Hannie$^{1}$; Ultach Enri²; Yuyun Umaidah ${ }^{3}$ \\ Information System \\ Universitas Singaperbangsa Karawang, Indonesia \\ www.unsika.ac.id \\ hannie@staff.unsika.ac.id¹ ,ultach@staff.unsika.ac.id², yuyun.umaidah@staff.unsika.ac.id ${ }^{3}$
}

\begin{abstract}
Karawang is one of the industrial cities. Most industry players look at Karawang as a strategic city to run a business. Many products have been produced from Karawang. However, there are lack in promoting, marketing the product and expanding the marketing area. The analysis of consumer satisfaction in Karawang is to determine the satisfaction of Karawang consumers to the prospects of promising online sales. Service attributes can be used to increase online sales in Karawang using the Customer Satisfaction Index (CSI) method. The CSI result is $78.43 \%$ which means that overall consumers who live in Karawang and have been shopped online are satisfied with the development of online shopping. This research was conducted in Karawang. The data used are primary data and secondary data. The sampling method used is a non-probability sampling method with sampling purposes as the non-probability sampling method.
\end{abstract}

Keywords: Consumer Satisfaction, Online Sales, Customer Satisfaction Index
Abstrak - Karawang merupakan salah satu kota industri. Kebanyakan pelaku industri melirik karawang sebagai kota yang strategis untuk menjalankan usaha bisnis. Banyak produk yang telah dihasilkan dari karawang. Akan tetapi promosi dan pemasaran penjualan produk kurang dalam memperluas area pemasaran. Analisis mengenai tingkat kepuasan konsumen karawang terhadap perkembangan penjualan online untuk mengetahui kepuasan konsumen karawang terhadap prospek penjualan online yang menjanjikan. Atribut-atribut pelayanan jasa dapat dijadikan masukkan dalam meningkatkan penjualan online di karawang dengan menggunakan metode Customer Satisfaction Index (CSI). Dengan memperoleh hasil CSI sebesar 78,43\% yang berarti secara keseluruhan konsumen yang tinggal di karawang dan pernah belanja online puas terhadap perkembangan penjualan online. Penelitian ini dilakukan di Karawang. Data yang digunakan adalah data primer dan data sekunder. Metode non probability sampling digunakan sebagai

pengambilan sampel, sedangkan jenis non probability sampling yang digunakan adalah sampling purpose.

Kata Kunci: Kepuasan Konsumen, Penjualan Online, Index Kepuasan Konsumen

\section{INTRODUCTION}

Online shopping is doing sales activities from looking for potential customers to offering products or goods by utilizing an internet network that is supported by a set of electronic devices. Nowadays, a good sales system is a system based on the network, which is online or called online shopping. The benefits of the system can be felt by both parties, the consumer and the seller. For consumers, this system is very helpful in finding products that buyers want, so consumers do not need to come directly to the location. Whereas for sellers, the online shopping system can expand the sales area and reduce expenses and increase revenue. In Indonesia most people are fond of shopping online. This thing can be happened because most people experience limited time to go shopping in stores and costs tend to be more expensive when calculated with travel costs (Situmeang, 2018) . The number of internet users in 2017 based on regions in Indonesia is 58.08\%, and the Java region is more dominant. Where the City of Karawang is a city located in West Java Province, Indonesia.

Karawang is a potential market for developing various types of businesses (Ramadhiani, 2016), it is all because of Karawang is the largest Industrial city in Indonesia (Nasihin, 2019) and the population continues to increase every year according to the Central Statistics Agency (BPS). 


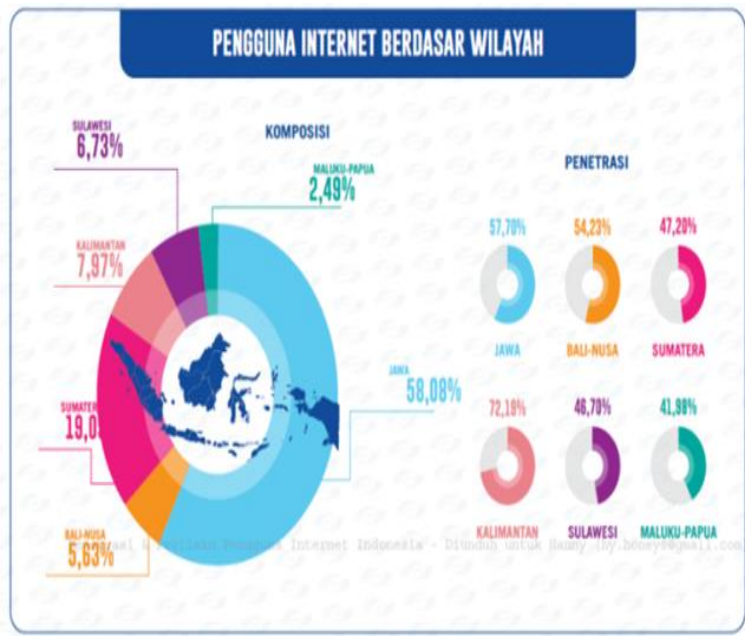

Source : (APJII, 2018)

Figure 1 The results of survey of internet users by region in Indonesia

Increasing population in Karawang has caused traffic conditions to become quite crowded, making people less interested in going to the store to shop, so they use online orders to purchase goods or services.

Table 1 The population of Karawang

\begin{tabular}{ccc}
\hline \multicolumn{3}{c}{ Population } \\
\hline 2010 & 2014 & 2015 \\
\hline 2.127 .791 & 2.250 .120 & 2.273 .579 \\
\hline
\end{tabular}

Source : (BPS Kabupaten Karawang, 2016)

The purpose of this study is to determine the effect of Karawang consumer satisfaction level on online sales, and the quality service attributes of consumer needs in online sales and to evaluate the quality of online sales service attributes that most influence Karawang consumer satisfaction.

\section{MATERIALS AND METHODS}

The research sample were carried out using non-probability sampling method, with a purposive sampling approach, namely the sampling technique with certain considerations or criteria (Randall, Coast, \& Leone, 2011)

Prospective respondents' criteria is Karawang consumers who have purchased products or services through online sales. The population in this study is unknown in number. If the population is unknown then you can use the Wibisione formula (Riduwan \& Akdon, 2013), that is:

$$
n=\left(\frac{Z \alpha / 2 \sigma}{e}\right)^{2}
$$

$$
\begin{array}{ll}
\mathrm{Z} \alpha & =\text { normal distribution table sample } \\
\sigma & =\text { Population Standard Deviation } \\
\mathrm{e} & =\text { Error Rate }
\end{array}
$$

\section{Validity Test}

After the final questionnaire is formed, the next step is to test the validity. The technique used is the following Pearson product moment correlation formula (Sugiyono, 2011):

$$
r \text { count }=\frac{n \Sigma X Y-\Sigma X \Sigma y}{\sqrt{n \Sigma X^{2}-(\Sigma X)^{2}}-\sqrt{n \Sigma Y^{2}-(\Sigma Y)^{2}}}
$$

Where:

$r_{\text {count }}=$ Correlation coefficient

$\mathrm{n}=$ Number of respondents

$\mathrm{X}=$ Score each question

$\mathrm{Y} \quad=$ Total score

Next is calculated by the t-test with the formula:

$$
t \text { count }=\frac{r \sqrt{n-2}}{\sqrt{1-r^{2}}}
$$

Where:

$$
\begin{array}{ll}
\mathrm{t} & =\text { Value } \mathrm{t}_{\text {count }} \\
\mathrm{r} & =\text { Correlation coefficient result } \mathrm{r}_{\text {count }} \\
\mathrm{n} & =\text { Number of respondents }
\end{array}
$$

Distributin (Table $t$ ) for $\alpha=0.05$ and degree of freedom $(\mathrm{dk}=\mathrm{n}-2)$, then if $\mathrm{t}$ hitung $>\mathrm{t}$ table means valid.

\section{Reability Test}

Spearman Browns formula is used to determine the results of the reliability test(prove) to measure stability and consistency of respondents in filling the questionnaire related to online sales (Riadi, 2016), as follows:

$$
r 11=\frac{2 . r b}{1+r b}
$$

Where:

$\mathrm{r}_{11}=$ Internal reability coefficient of all items

$\mathrm{r}_{\mathrm{b}}=$ Correlation of moment product

Distribution (table $r$ ) for $\alpha=0.05$ and degree of freedom $(\mathrm{dk}=\mathrm{n}-2)$, then if $\mathrm{r} 11>\mathrm{r}$ tabel means reliable.

\section{Importance Performance Analysis}

In analyzing this research data, the Importance Performance method is used to answer the problem formula regarding the level of satisfaction of Karawang consumers towards Oline sales.

Where:

$\mathrm{n} \quad=$ sample 


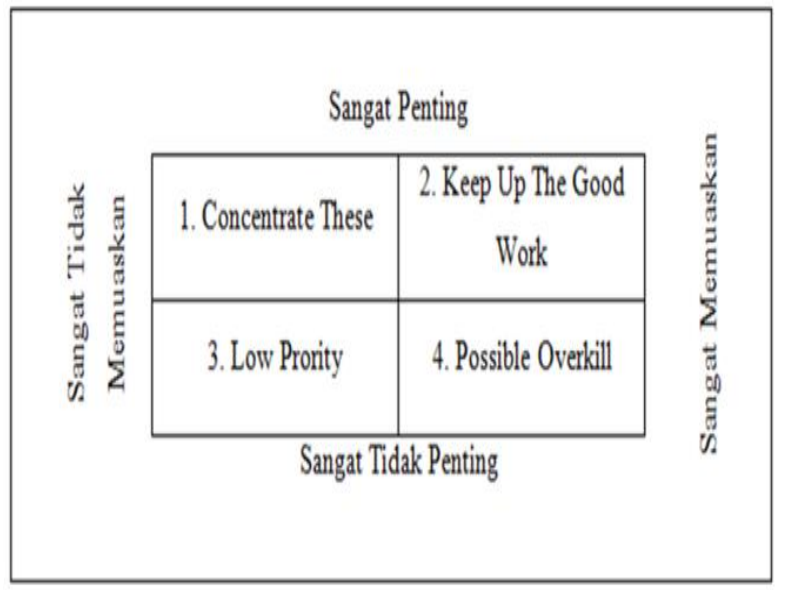

Source: (Nugraha, Harsono, \& Adianto, 2014)

Figure 2 Importance Performance map

Based on the assessment of the level of importance and the performance appraisal (satisfaction), the results will be generated regarding the level of suitability between the level of importance and the level of implementation by Karawang consumers measured using a Likert 5 scale.

Table 2. Value according to level of satisfaction and level of performance

\begin{tabular}{ccc}
\hline \multicolumn{3}{c}{ level of performance } \\
\hline 1 & Level of Satisfaction & $\begin{array}{c}\text { Level of } \\
\text { Performance }\end{array}$ \\
\hline 2 & Unimportant & Bery Bad \\
\hline 3 & Normal & Normal \\
\hline 4 & Important & Good \\
\hline 5 & Very Important & Very Good \\
\hline
\end{tabular}

Source: (Pohandry, Sidarto, \& Winarni, 2013)

\section{Customer Satisfaction Index (CSI)}

The Customer Satisfaction Index is used to measure the level of Karawang customer satisfaction on online sales service performance. To find out the value of CSI, the following steps can be taken (Sudarno, Rusgiyono, Hoyyi, \& Listifadah, 2011) :

1. Determining the Mean Importance Score (MIS) of each variable.

2. Making Weight Factors (WF) per variable. This weight is the percentage of MIS values per variable against the total MIS of all variables.

3. Determining the Mean Satisfaction Score (MSS) for each attribute.
4. Making Weight Score (WSk) for each variable. This weight is a multi-location between WFk and $M S S k$

5. Determining Customer Satisfaction Index (CSI)

\section{Data Adequacy Test}

Adequacy Test The amount of respondents that will be used in the study is using the Wibisono formula because the population is unknown:

$$
n=\left(\frac{Z \alpha / 2 \sigma}{e}\right)^{2}=\left(\frac{(1.96) *(0,25)}{0,05}\right)^{2}=96,04 \approx 97 .
$$

The specified level of precision is $5 \%$, a confidence level of $95 \%$ and an estimated error of $\mu$ less than 0.05. Because $\alpha=0.05, \mathrm{Z} 0.05=1.96$ and the standard deviation of the population is 0.25 . So that the random sample results obtained were 96.04 or 97 . So the samples taken were 97 respondents. Researchers distributed questionnaires to 97 consumers for 2 weeks, starting from 21 September 2018 to 5 October 2018

\section{Description of Respondents}

1. Gender

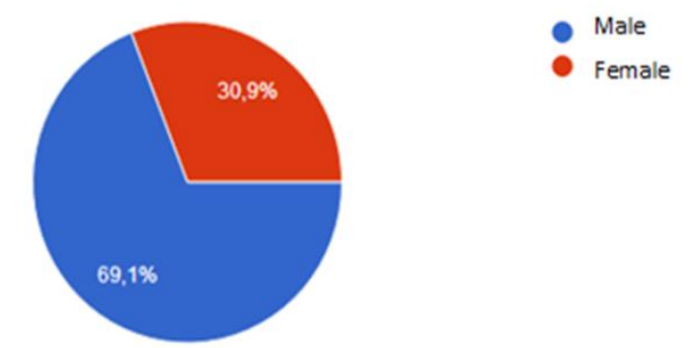

Source : (Hannie, Umaidah, \& Enri, 2018)

Figure 3 Characteristics of respondents based on gender

2. Age

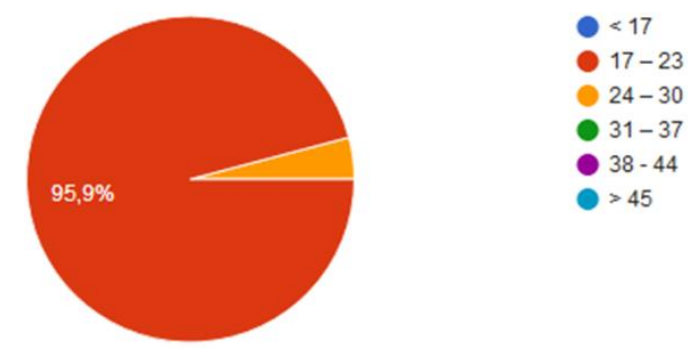

Source: (Hannie et al., 2018)

Figure 4 Characteristics of respondents based on age 
3. Elektronik media used for online shopping

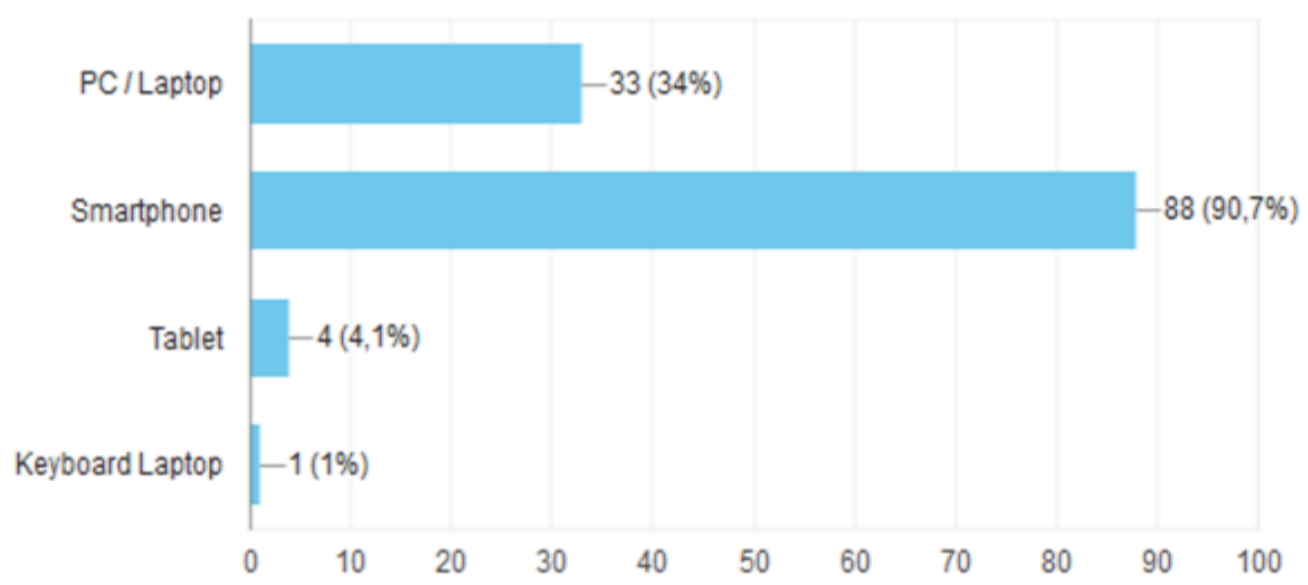

Source: (Hannie et al., 2018)

Figure 5 Characteristics of respondents based on what electronic media is used for online shopping

\section{Importance Analysis - Performance's Results}

Cartesian diagram is a diagram divided into four sections which are bounded by two lines intersecting perpendicular to the points $(\mathrm{x}, \mathrm{y})$, where $\mathrm{x}$ is the average of the implementation's score of all factors and $y$ is the average of the mean the importance's score of all factors affecting customer satisfaction (Supranto, 2011). The results of the translation of the Importance Performance Analysis quadrant can be seen in Figure 6 below:

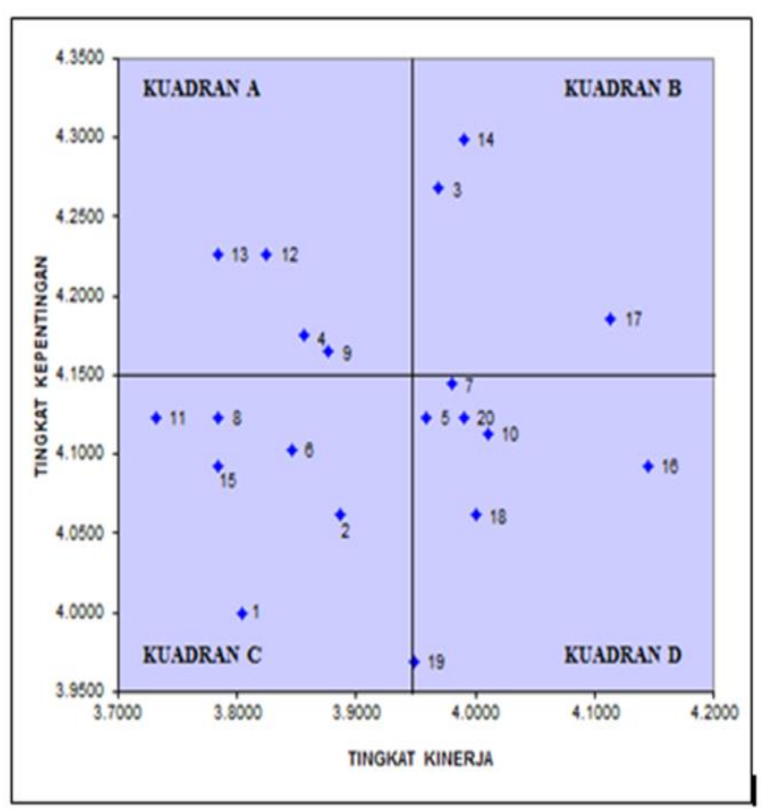

Source: (Hannie et al., 2018)

Figure 6 Cartesian Diagram Attributes of the level of satisfaction of karawang consumers to the development of online sales

\section{Customer Satisfaction Index Analysis's Results}

The overall value of customer satisfaction can be seen by looking for the value of the CSI. The results of this study obtained CSI value of $78.43 \%$, which means that overall consumers who live in Karawang and have been shopping online are satisfied with online sales.

Table 3. Customer Satisfaction Index (CSI) Calculation

\begin{tabular}{|c|c|c|c|c|}
\hline No. & $\begin{array}{c}\text { Averag } \\
\text { e Level } \\
\text { of } \\
\text { Expect } \\
\text { ation } \\
\text { (Y) }\end{array}$ & $\begin{array}{c}\text { Importanc } \\
e \\
\text { Weighting } \\
\text { Factor } \\
\text { (percent) }\end{array}$ & $\begin{array}{c}\text { Average } \\
\text { Level of } \\
\text { Perfor } \\
\text { mance } \\
\text { (X) }\end{array}$ & $\begin{array}{c}\text { Weigh } \\
\text { ted } \\
\text { Score } \\
\text { (WS) }\end{array}$ \\
\hline 1. & 3.381 & 4.656 & 3.804 & 0.177 \\
\hline 2. & 3.505 & 4.826 & 3.887 & 0.188 \\
\hline 3. & 3.907 & 5.380 & 3.969 & 0.214 \\
\hline 4. & 3.392 & 4.670 & 3.856 & 0.180 \\
\hline 5. & 3.608 & 4.968 & 3.959 & 0.197 \\
\hline 6. & 3.608 & 4.968 & 3.845 & 0.191 \\
\hline 7. & 3.907 & 5.380 & 3.979 & 0.214 \\
\hline 8. & 3.278 & 4.514 & 3.784 & 0.171 \\
\hline 9. & 3.392 & 4.670 & 3.876 & 0.181 \\
\hline 10. & 3.856 & 5.309 & 4.010 & 0.213 \\
\hline 11. & 3.134 & 4.315 & 3.732 & 0.161 \\
\hline 12. & 3.433 & 4.727 & 3.825 & 0.181 \\
\hline 13. & 3.515 & 4.840 & 3.784 & 0.183 \\
\hline 14. & 3.722 & 5.124 & 3.990 & 0.204 \\
\hline 15. & 3.412 & 4.698 & 3.784 & 0.178 \\
\hline 16. & 4.041 & 5.564 & 4.144 & 0.231 \\
\hline 17. & 4.041 & 5.564 & 4.113 & 0.229 \\
\hline 18. & 3.907 & 5.380 & 4.000 & 0.215 \\
\hline
\end{tabular}




\begin{tabular}{ccccc}
\hline & $\begin{array}{c}\text { Averag } \\
\text { e Level } \\
\text { of } \\
\text { Expect } \\
\text { ation } \\
\text { (Y) }\end{array}$ & $\begin{array}{c}\text { Importanc } \\
\text { Weighting } \\
\text { Factor } \\
\text { (percent) }\end{array}$ & $\begin{array}{c}\text { Average } \\
\text { Level of } \\
\text { Perfor } \\
\text { mance } \\
\text { (X) }\end{array}$ & $\begin{array}{c}\text { Weigh } \\
\text { ted } \\
\text { Score } \\
\text { (WS) }\end{array}$ \\
\hline 19. & 3.711 & 5.110 & 3.948 & 0.202 \\
\hline 20. & 3.876 & 5.337 & 3.990 & 0.213 \\
\hline $\begin{array}{c}\text { Tot } \\
\text { al }\end{array}$ & $\mathbf{7 2 . 6 2 8 9}$ & $\mathbf{1 0 0 . 0 0}$ & $\mathbf{3 . 9 1 3 9}$ \\
\hline \multicolumn{5}{c}{ Weighted Total } \\
\hline \multicolumn{5}{c}{ Satisfaction Index } \\
\hline
\end{tabular}

Source: (Hannie et al., 2018)

\section{CONCLUSION}

The conclusion of the results and discussion of the analysis of the level of satisfaction of karawang consumers of online shopping development with the Customer Satisfaction Index method are many consumers who live in Karawang have made online shopping transactions using Smarthphone. Where the dominant who conduct these transactions are men between the ages of $17-23$ and products that are bought by fashion. This is natural because smartphones are smart phones or cellular phones that are equipped with advanced features and are capable of a computer. Men between the ages of 17-23 years are the process of finding identity so they have to keep up with the trend of fashion trends. The result of this study obtained CSI value of $78.43 \%$, which means that overall consumers who live in Karawang and have been shopping online are satisfied with the development of online sales. Seeing from the Weighting Score Rating, the quality of service attributes, the level of expectations and performance levels that are the main priority of karawang consumers prefer online shopping, which can save time because there is no need to visit the store.

\section{REFERENCES}

APJII. (2018). Hasil Survei Penetrasi dan Perilaku Pengguna Internet Indonesia 2018. Retrieved from

https://apjii.or.id/content/read/39/410/Has il-Survei-Penetrasi-dan-Perilaku-PenggunaInternet-Indonesia-2018

BPS Kabupaten Karawang. (2016). Jumlah Penduduk dan Rasio Jenis Kelamin Menurut Kecamatan di Kabupaten Karawang, 2015$2016 . \quad$ Retrieved from https://karawangkab.bps.go.id/dynamictable /2018/07/17/37/jumlah-penduduk-danrasio-jenis-kelamin-menurut-kecamatan-dikabupaten-karawang-2015-2016.html

Hannie, Umaidah, Y., \& Enri, U. (2018). Laporan Akhir Penelitian DIPA Unsika. Karawang.

Nasihin, H. (2019). 5 Alasan Prospek Investasi di Karawang Terus Meningkat. Retrieved from https://www.kompasiana.com/herunasihin/ 5c4580bc6ddcae1de2697d22/5-alasanprospek-investasi-di-karawang-terusmeningkat

Nugraha, R., Harsono, A., \& Adianto. (2014). UsulanPeningkatan Kualitas Pelayanan Jasa pada Bengkel "X" Berdasarkan Hasil Matrix Importance-Performance Analysis (Studi kasus di Bengkel AHASS PD. Sumber Motor Karawang). Jurnal Online Institut Teknologi Nasional, 1(3), 221-231.

Pohandry, A., Sidarto, S., \& Winarni. (2013). Analisis Tingkat Kepuasan Pelanggan Dengan Menggunakan Metode Customer Satisfaction Index dan Importance Performance Analysis Serta Service Quality. Jurnal REKAVASI, 1(1), 21-29.

Ramadhiani, A. (2016). Industri Terus Tumbuh, Karawang Diincar Pengembang Besar. Retrieved from https://properti.kompas.com/read/2016/05 /09/210000821/Industri.Terus.Tumbuh.Kar awang.Diincar.Pengembang.Besar?page=all

Randall, S., Coast, E., \& Leone, T. (2011). Cultural constructions of the concept of household in sample surveys. Population Studies, 65(2), 217-229.

https://doi.org/10.1080/00324728.2011.57 6768

Riadi, E. (2016). Statistika Penelitian (Analisis Manual Dan IBM SPSS). Yogyakarta: ANDI.

Riduwan, \& Akdon. (2013). Rumus dan Data dalam Aplikasi Statistika. Bandung: Alfabeta.

Situmeang, R. R. (2018). DAMPAK BISNIS ONLINE DAN LAPANGAN PEKERJAAN TERHADAP PENINGKATAN PENDAPATAN MASYARAKAT (STUDI KASUS JASA BISNIS ONLINE TRANSPORTASI GRAB DI KOTA MEDAN). AJIE, 3(3), 319-335. Retrieved from https://journal.uii.ac.id/ajie/article/view/11 $620 /$ 
Sudarno, Rusgiyono, A., Hoyyi, A., \& Listifadah. (2011). Analisis Kualitas Pelayanan Dan Pengendalian Kualitas Jasa Berdasarkan Persepsi Pengunjung. Media Statistika, 4(1), 33-45.

Sugiyono. (2011). Statistika untuk Penelitian (Cetakan ke-3). Bandung: CV ALFABETA. 